\title{
Blended Learning Method in a Sports School
}

\author{
Analysis of Need Assessment and Learning Environment
}

\author{
Sapto Adi \\ Ilmu Keolahragaan, Universitas Negeri Malang, \\ Malang, Indonesia \\ sapto.adi.fik@um.ac.id \\ Moh. Fathur Rohman \\ Pendidikan Olahraga, Universitas Negeri Jakarta \\ Jakarta, Indonesia
}

\author{
Imam Hariadi \\ Pendidikan Kepelatihan, Universitas Negeri Malang \\ Malang, Indonesia
}

\author{
Desi Ariwinanti \\ Ilmu Kesehatan Masyarakat, Universitas Negeri Malang, \\ Malang,Indonesia
}

\begin{abstract}
Sportsschool has different learning characteristics compared to the general schools. The learning activities in sports school are less than an ordinary student has. Therefore, it is needed to be more focused. Currently, the students at the sports school have not been supported by learning technology product. This research aimed to analyze the learning characteristics and assess the needs of a teacher who teaches at a sports school which uses blended learning. The research methodology was mixed methods of quantitative descriptive and qualitative approaches using survey. The data were collected by questionnaire, interview, observation and documentation. The research samples were taken from five sports schools in Indonesia consisting of $\mathbf{5 7}$ teachers, 5 headmasters, and 500 students. The research results showed $87 \%$ of teachers have not implemented the blended learning, $7.7 \%$ of them have developed the computer-based learning sources, and only $27 \%$ of them using the internet as a learning source for students. $96.4 \%$ of teachers admit the need to develop the blended learning in their teaching. The result of this research showed, in general, the sports school still uses the conventional method, and the blended learning is still rarelyapplied. However, the teachers in thesports school express the need to develop blended learning in their learning environment.
\end{abstract}

Keywords—need assessment, learning environment, blended learning, sports school

\section{INTRODUCTION}

A sports school is one alternative to nurture the talented sportsman in the pyramid of achievement. By studying in the sports school, athletes can still study and reach their good achievement both academically and in the sport. The students are ensured that their sports activities will not be restricted and they do not have to choose between studying and practicing sports.

It is necessary to increase the effectiveness of sports schools by designing a model which suits both aspects of academic and sport. Hence, the learning method in the sports school needs to be differentiated from the general school which focuses more on the academic and homework responsibility.
The main role of a sportsman is to practice which might cause his role as an ordinary student is restricted. There is an emerging need to design a learning method which allows the students of sports school to study anytime, anywhere with anyone. Their learning process will not be limited by time and space. A sports school needs to design a learning method to support the learning environment of its students.

Nowadays, the internet can be very useful to the learning process at sports school. By developing the electronic-based learning sources, the students can learn anytime and anywhere in accordance with their personal schedule. Several learning sources which can be used by offline and online include the interactive multimedia, online learning, mobile learning, etc.

To develop a learning method which can be beneficial in the future as well as to build athlete achievement are the urgent needs. A great sports school will produce a great athlete achievement not only in sports but in academic as well. The athlete will achieve his fullest potential. Furthermore, the school will continue producing more talented sportsmen.

\section{BLENDED LEARNING}

A research done by [1] found that blended learning can improve the student's learning achievement and decrease the drop-out rate compared to fully online learning. Furthermore, blended learning is also proven to be better compared to the ordinary face-to-face learning.

Although there is no standard proportion of face-to-face presence and physical absence, certainly theBlended Learningbased learning always combines face-to-face and e-Learning activities as an effort to facilitate the learning [2].

Blended learning can improve the learning result and can benefit the communication in three different forms which are classroom, offline and online. A research showed that blended learning can create a better solidarity among classmates compared to the ordinary classroom or full-online learning [3]. Blended learning can increase the employee's productivity than the single learning method [4]. 
The development of blended learning in sports school is to provide learning sources that can suit the different characteristics of the students. Hence, the learning process can be more interesting, effective and efficient. The next stage is to decide which the best scenario to explain different material in sports learning process. For example, the offline method is to explain the technique, the internet is to see the application of the technique in a real sports event, and to demonstrate and practice the discipline by the face-to-face method. The key message is that blended learning facilitates the learning process by providing various learning sources in regards to different characteristics of the students. Learning process should motivate the students to utilize the face-to-face classroom to question the teacher about things that they do not understand from the online material. Furthermore, the online and offline classes can help an individual (an athlete for example) to arrange his study time between the time of the regular practice and the competition.

\section{A. Suggestions for Valuable Introductions, Sections and Conclusions}

Learning process that suits the needs of students at the sports school has not been defined. Regarding the student's roles both as a student and a professional athlete, the learning process should consider the best combination and suitable proportion of studying and practicing.

To facilitate the student's need, an innovation in learning models needs to be developed. The model should comprise the need of direct learning (face-to-face), indirect learning (online) and independent learning (offline). The model that covers these three types of learning is blended learning which can be conducted anywhere and anytime. However, to implement the blended learning, the human resource and the infrastructure of sports school need to be well prepared.

The research collects the data on the learning environment and the need assessment of blended learning. From the data shown, blended learning is still not wide-implemented in sports schools.

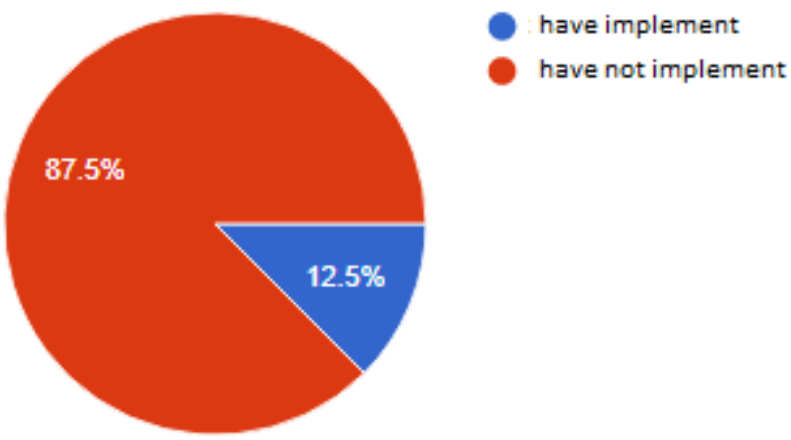

Fig. 1. Blended learning implementation in sports schools.
Based on the results of questionnaires and observations, $87 \%$ of all teachers have not implemented blended learning. Therefore, their style of teaching is still dominated by face-toface classroom. The blended learning model needs the practicality and preparedness of the teachers. Furthermore, infrastructure or learning facilities that can support blended learning needs to be addressed. In the same side, Wasis' [5] research found that 466 subjects with details of $23 \%$ of lecturers and $77 \%$ of teachers were scattered from 20 cities and most of the respondents did not understand the blended learning, most of them have never heard.

The utilization of private facilities is mainly to create the student's assignments and design the lesson plan. The facilities have not been used to develop various electronic-based learning sources such as audio (17,3\%), video (25\%), multimedia interactive learning $(7,7 \%)$, internet-based learning sources $(21,2 \%)$, and mobile-based learning sources $(5,8 \%)$. The condition is due to the lack of teacher's skill in operating software to develop various electronic-based learning sources. This result was different with another research conducted by [5] he found that in the learning activities, most of the respondents already have basic computer skills: word, spreadsheets, and processing multi-media (text, images, video, animation).

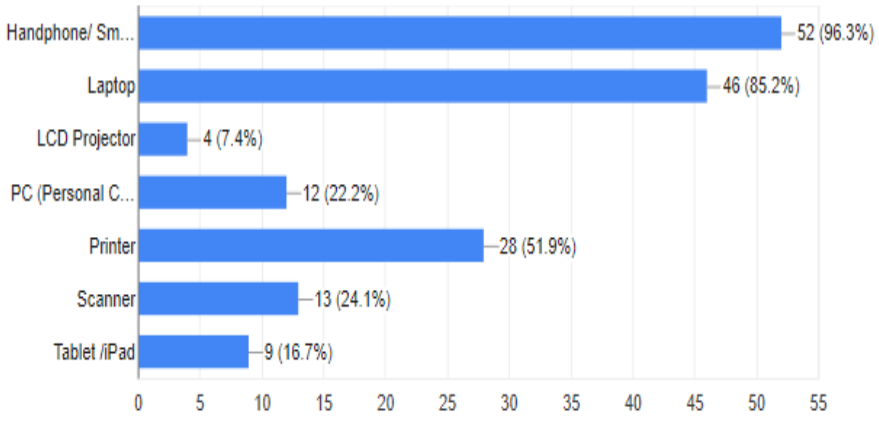

Fig. 2. Learning facilities owned by the teachers

From the data, the learning facilities owned by the teachers actually support the blended learning. Nevertheless, they have not yet utilized them properly.

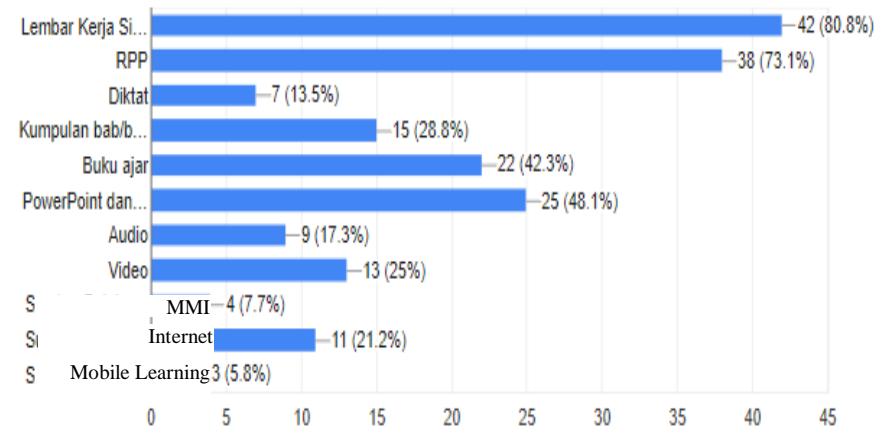

Fig. 3. Learning sources owned or developed by the teachers 


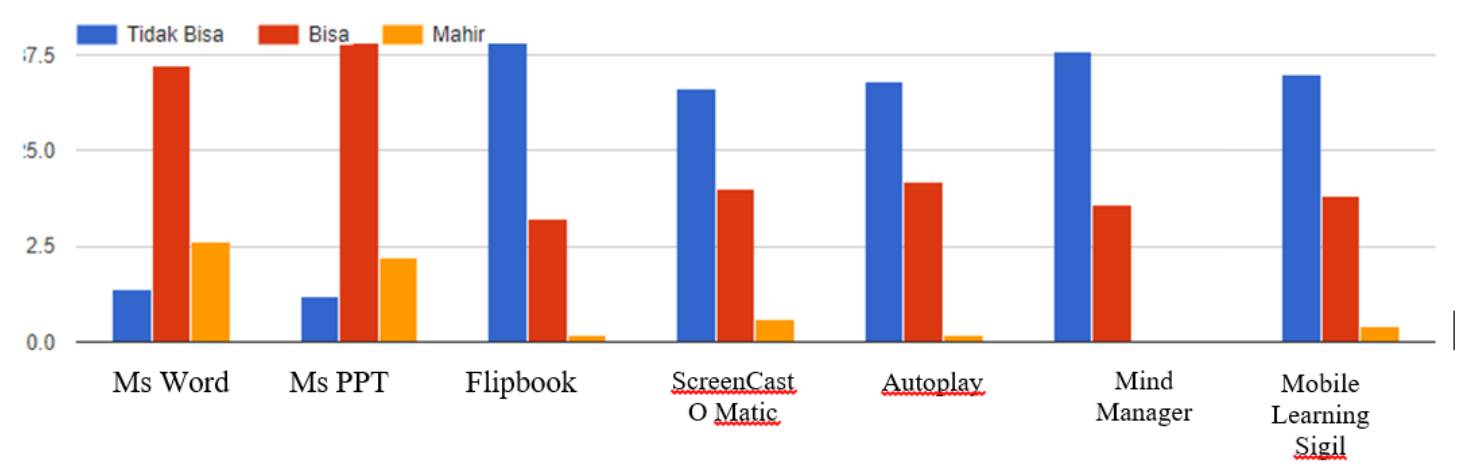

Fig. 4. The level of teacher's skill to operate the software to develop the electronic-based learning sources

To find out the teachers' readiness in designing and implementing blended learning, the researchers traced the teachers' ability to develop various offline, online and face-toface learning resources. Based on the responses given, some teachers can develop face-to-face learning resources, but for offline and online learning resources in blended learning, they still have not be able to develop. The diagram showed that the ability to operate flipbook, autoplay, mind manager, mobile learning, and screencast of matic still visible blue diagram more dominant which shows that most have not been able to meet the needs of blended learning implementation. Blended learning is not just about face to face, but the teacher should facilitate the learner to learn independently outside the classroom.

The teachers at sports school generally want to develop their method to be better yet, they have not attained the skill to develop various learning resources, particularly the electronicbased ones.

After knowing the composition of blended learning and the teacher's readiness level, the researchers then provide the key questions related to the teachers' needs of learning-based blended learning development in sports schools. Here are the responses:

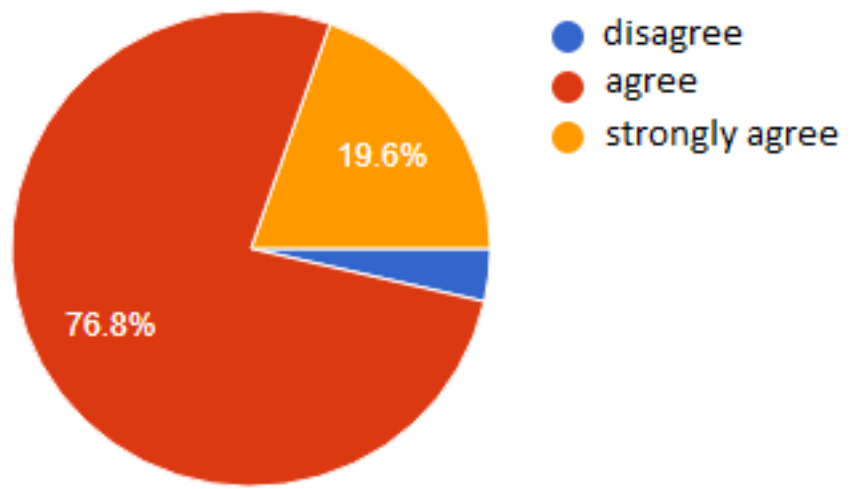

Fig. 5. Teachers' response of learning-based blended learning development needs in sports schools

From the data, it is shown that $76 \%$ of the teachers agreed to develop the blended learning method in sports schools, $19.6 \%$ of the teachers highly agreed to develop the blended learning method in sports schools, and only $3.6 \%$ of teachers did not agree to develop the blended learning method in sports schools.

\section{DISCUSSION}

Blended learning combines various learning process interactions, thus giving students more opportunities to learn by accessing different digital learning resources provided by the teachers. To fulfil the need for various interactions and expand the opportunity to learn, the teachers need to prepare the blended learning method. In regards to the sports school, the classroom should not be the ordinary type, instead, it needs a bigger and more flexible place. Blended learning can accommodate a face-to-face classroom, online and technologybased approach [6]. The learning process in blended learning involves synchronous (real-time studying) and asynchronous (delayed studying where the teachers and the students interact by using the information technology media and online sessions). The interaction needs to be created to gain the 
knowledge. Peer interaction among students is also important to help them in brainstorming and solving the problems.

The teacher's facilities are adequate already to provide several digital learning resources. Nevertheless, the teachers need to learn the skill to master the development of these digital resources. The teachers admit that blended learning needs to be developed to increase the effectivity, efficiency and to engage the students to learn. Dwiyogo [5] stated that blended learning can increase the effectivity, efficiency and can motivate people to interact in the various learning environment.

The need assessment shows that the teachers responsed positively to the development of blended learning in the sports schools. Furthermore, the data which showed the conventional learning environment were still the majority in the current sports schools that open the opportunity to develop the blended learning. However, there is the need to conduct the further research to find the best composition of blended learning which is in accordance with the needs of sports schools.

The sports school students' characteristic is mostly living in the boarding house with the strict regulations regarding the use of smartphone and the internet. This fact needs to be put into consideration.

\section{CONCLUSION}

The data collected from the teachers at the sports school show the potential to develop the blended learning in the sports school where the teachers have already had the facilities but not yet the skills to develop the electronic-based learning resources. The majority of the teachers admitted the need to develop the blended learning for sports schools. The further research needs to be done to formulate the best composition of face-to-face classroom, offline and online interaction which corresponds the needs of sports school.

Several things to be considered in the future research are the development of online class and mobile learning due to the sports school strict regulation regarding the use of smartphones both in school area and boarding house. Furthermore, there is no internet provision (WIFI) for students in those two areas.

\section{REFERENCES}

[1] C. Dziuban, J. Hartman, and P. Moskal, "Blended learning," Educause Centre for Applied Research Bulletin., 2004. .

[2] S. Ranganathan, S. Negash, and M. V. Wilcox, "Hybrid Learning: Balancing Face-to-Face and Online Class Sessions," Proc. 2007 South. Assoc. Inf. Syst. Conf., pp. 178-182, 2017.

[3] A. P. Rovai and H. Jordan, "Blended learning and sense of community: A comparative analysis with traditional and fully online graduate courses," Int. Rev. Res. Open Distrib. Learn., vol. 5, no. 2, pp. 2-13, 2004.

[4] J. Barbian, "Blended Works: Here's Proof!," Online Learn., vol. 6, no. 6, 2002.

[5] W. D. Dwiyogo, "Pembelajaran Berbasis Blended Learning," 2013.

[6] D. R. Garrison and N. Vaughan, Blended Learning in Higher Education: Framework, Principles, and Guidelines. John Wiley \& Sons., 2008. 